\title{
Contribution of land use changes to near- surface air temperatures during recent summer extreme heat events in the Phoenix Metropolitan Area
}

\section{Article}

Published Version

Grossman-Clarke, S., Zehnder, J. A., Loridan, T. and Grimmond, C.S. B. (2010) Contribution of land use changes to near-surface air temperatures during recent summer extreme heat events in the Phoenix Metropolitan Area. Journal of Applied Meteorology and Climatology, 49 (8). pp. 1649-1664. ISSN 1558-8432 doi: https://doi.org/10.1175/2010JAMC2362.1 Available at https://centaur.reading.ac.uk/34733/

It is advisable to refer to the publisher's version if you intend to cite from the work. See Guidance on citing.

Published version at: http://dx.doi.org/10.1175/2010JAMC2362.1

To link to this article DOI: http://dx.doi.org/10.1175/2010JAMC2362.1

Publisher: American Meteorological Society

All outputs in CentAUR are protected by Intellectual Property Rights law, including copyright law. Copyright and IPR is retained by the creators or other copyright holders. Terms and conditions for use of this material are defined in the End User Agreement. 


\section{www.reading.ac.uk/centaur}

\section{CentAUR}

Central Archive at the University of Reading

Reading's research outputs online 


\title{
Contribution of Land Use Changes to Near-Surface Air Temperatures during Recent Summer Extreme Heat Events in the Phoenix Metropolitan Area
}

\author{
SUSANNE GROSSMAN-CLARKE \\ Global Institute of Sustainability, Arizona State University, Tempe, Arizona \\ JOSEPH A. ZEHNDER \\ Department of Atmospheric Sciences, Creighton University, Omaha, Nebraska \\ ThOMAs LORIDAN AND C. Sue B. GRIMMOND \\ Department of Geography, King's College London, London, United Kingdom
}

(Manuscript received 3 August 2009, in final form 18 March 2010)

\begin{abstract}
The impact of 1973-2005 land use-land cover (LULC) changes on near-surface air temperatures during four recent summer extreme heat events (EHEs) are investigated for the arid Phoenix, Arizona, metropolitan area using the Weather Research and Forecasting Model (WRF) in conjunction with the Noah Urban Canopy Model. WRF simulations were carried out for each EHE using LULC for the years 1973, 1985, 1998, and 2005. Comparison of measured near-surface air temperatures and wind speeds for 18 surface stations in the region show a good agreement between observed and simulated data for all simulation periods. The results indicate consistent significant contributions of urban development and accompanying LULC changes to extreme temperatures for the four EHEs. Simulations suggest new urban developments caused an intensification and expansion of the area experiencing extreme temperatures but mainly influenced nighttime temperatures with an increase of up to $10 \mathrm{~K}$. Nighttime temperatures in the existing urban core showed changes of up to $\sim 2 \mathrm{~K}$ with the ongoing LULC changes. Daytime temperatures were not significantly affected where urban development replaced desert land (increase by $\sim 1 \mathrm{~K}$ ); however, maximum temperatures increased by $\sim 2-4 \mathrm{~K}$ when irrigated agricultural land was converted to suburban development. According to the model simulations, urban landscaping irrigation contributed to cooling by $0.5-1 \mathrm{~K}$ in maximum daytime as well as minimum nighttime 2-m air temperatures in most parts of the urban region. Furthermore, urban development led to a reduction of the already relatively weak nighttime winds and therefore a reduction in advection of cooler air into the city.
\end{abstract}

\section{Introduction}

Urbanization is one of the most powerful and visible anthropogenic forces on Earth. Today there are over 400 cities in the world with populations of over 1 million and, in the foreseeable future, virtually all population growth is projected to occur in urban areas (United Nations 2007). Expansion of cities to accommodate increasing population has global, regional, and local effects on weather and climate because of land use-land

Corresponding author address: Dr. Susanne Grossman-Clarke, Arizona State University, Global Institute of Sustainability, P.O. Box 875402, Tempe, AZ 85287-5402.

E-mail: sg.clarke@asu.edu cover (LULC) changes and accompanying effects on physical processes governing energy, momentum, and matter exchange between land surfaces and the atmosphere (Kabat et al. 2004; Pielke et al. 2002; Dickinson 2003; Cotton and Pielke 2007; Zhang et al. 2009). Urbanization significantly impacts regional near-surface air temperatures, wind fields, the evolution of the planetary boundary layer (PBL), and precipitation, subsequently influencing air quality, human comfort, and health. Increased scientific interest in capturing the details of meteorological fields at the urban scale results from both the need to understand and forecast the environmental conditions in cities where most humans live and by the improved computing ability to resolve heterogeneity and physical characteristics of urban areas in climate and 
mesoscale meteorological modeling (Brown 2000; Martilli 2007).

In this study the Weather Research and Forecasting (WRF) Model (Skamarock et al. 2008) together with the Noah Urban Canopy Model (Noah UCM) by Kusaka and Kimura (2004) was used to investigate how historic (1973-2005) LULC changes during a period of rapid urbanization of the arid Phoenix, Arizona, metropolitan area contributed to the spatial extent and intensity of recent summer extreme heat events (EHEs) in the region. The Noah UCM has been successfully applied and evaluated in various cities including Houston, Texas (Chen et al. 2004), Oklahoma City, Oklahoma (Liu et al. 2006), and Hong Kong, China (Lo et al. 2007). The Noah $\mathrm{UCM}$ is currently being rigorously tested offline against surface-energy balance measurements (Loridan et al. 2010).

During three decades of rapid urbanization, the population of the Phoenix metropolitan region increased by $\sim 45 \%$ per decade from about 971000 to nearly 4 million currently. This increase in population was accompanied by an increase in minimum nighttime air temperature differences between urban and rural sites of up to $10 \mathrm{~K}$ (Brazel et al. 2000, 2007). It is expected that the population will grow to $\sim 10$ million by 2050 (Maricopa Association of Governments 2007). Based on the available LULC data it was determined that the extent of the built-up urban area had increased to about $2500 \mathrm{~km}^{2}$ by 2005 , and that is large enough to influence mesoscale processes. Between 1900 and 1995 there was a transition from predominantly irrigated agricultural to suburban land use in the region. Currently, however, large tracts of undeveloped Sonoran desert are being converted to urban land use.

The local-scale response to larger-scale meteorological forcing is determined in large part by surface characteristics such as albedo, emissivity, thermal capacity, available moisture, and surface roughness-all influencing the energy, mass, and momentum exchange between the surface and the atmosphere. In urban areas the surfaceenergy balance characteristics differ as the building materials lead to an increased surface volumetric heat-storage capacity and thermal conductivity, radiation trapping because of the vertical structure of buildings, and anthropogenic heat release (Oke 1987).

Understanding the effects of LULC changes on nearsurface air temperature is particularly important in this arid region to enhance the adaptive capacity of a city that regularly experiences high average daily summertime temperatures and extended periods without rainfall. Multiday EHEs strongly influenced human comfort and health. Arizona led the United States in deaths from heat exposure between 1993 and 2002 (Centers for Disease Control 2005). Large segments of the population are well adapted to extreme heat through access to air conditioning in their homes. However, Phoenix region studies show that minorities with higher poverty rates experience high vulnerability to extreme heat because of lower economic means to adjust to high temperatures as well as higher air temperatures in their neighborhoods (Harlan et al. 2006; Ruddell et al. 2009). An important factor for air temperature variability within the Phoenix metropolitan region is the presence of open space and extensive cover of irrigated landscape vegetation, which is less abundant in economically disadvantaged neighborhoods (Harlan et al. 2006; Jenerette et al. 2007).

Here, the WRF/Noah UCM modeling system is applied to analyze the effects of urban land use changes on the magnitude of day- and nighttime temperatures during the four most recent EHEs (2003, 2005, 2006, and 2007). Landsat satellite Multispectral Scanner System, Thematic Mapper, and Enhanced Thematic Mapper derived land use data for 1973 (Moeller 2005), 1985, 1998 (Stefanov et al. 2001), and 2005 (Buyantuyev 2005) are used to provide the basis for model parameter values. The following questions are addressed: Has urban development led to an intensification and expansion of the area characterized by extreme temperatures? Did urban landscaping and agricultural irrigation provide significant cooling? Did urban roughness effects and the accompanying reduction of mean horizontal wind speed due to vertical momentum transfer dampen beneficial effects of horizontal wind speed and advection of cooler air into the urban area?

The EHEs and their occurrence in Phoenix, as well as the setup of the WRF model simulations are described (section 2). The model is evaluated with data from surface weather stations. The influence of historical land use changes on near-surface air temperatures and wind speeds are discussed (section 3).

\section{Data, model, and analysis methods}

\section{a. Site description}

Phoenix is located in the center of the Salt River valley, which is a broad, oval-shaped, nearly flat plain at a mean elevation of about $335 \mathrm{~m}$ MSL. The climate is arid subtropical with high summer and mild winter daytime temperatures. Typically there is little synoptic forcing in the desert southwest during the spring, early and late summer, and fall months, which are generally dry.

Several studies predict a likely increase in frequency, duration and severity of EHEs in the western and southwestern United States due to global climate change (e.g., Meehl and Tebaldi 2004; Seager et al. 2007; Diffenbaugh et al. 2008). The present study is concerned with the 
TABLE 1. EHEs and the highest recorded maximum and minimum daily temperatures during each period for Phoenix Sky Harbor station (1961-2008) based on Huth et al. (2000) criteria.

\begin{tabular}{ccc}
\hline & \multicolumn{2}{c}{ Highest obs daily temperature $\left({ }^{\circ} \mathrm{C}\right)$} \\
\cline { 2 - 3 } EHE & Max & Min \\
\hline 25-28 Jun 1979 & 47.2 & 26.7 \\
7-9 Jun 1985 & 46.1 & 27.8 \\
21-23 Jun1988 & 46.7 & 31.7 \\
3-5 Jul 1989 & 47.8 & 30.6 \\
25-28 Jun1990 & 50.0 & 33.9 \\
26-29 Jul 1995 & 49.5 & 31.7 \\
12-16 Jul 2003 & 46.7 & 35.6 \\
12-17 Jul 2005 & 46.7 & 33.9 \\
21-24 Jul 2006 & 47.8 & 35.0 \\
3-6 Jul 2007 & 46.7 & 33.9 \\
\hline
\end{tabular}

influence of LULC changes on near-surface air temperature during EHEs. It does not address the influence of past or potential future climate change on the occurrence of EHEs. EHEs were identified based on three criteria that are related to the exceedance of two near-surface air temperature thresholds $\left(T_{1}, T_{2} ; 97.5\right.$ th and 81 st percentile of the distribution of maximum temperatures) for recorded summertime air temperatures (June-August) between 1961 and 1990 (Huth et al. 2000; Meehl and Tebaldi 2004). Three criteria characterize a continuous period as an EHE: 1) the daily maximum temperature must be above $T_{1}$ for at least three consecutive days, 2) the average of the daily maximum temperatures of the entire period must be above $T_{1}$, and 3 ) the daily maximum temperature must be above $T_{2}$ for every day of the entire period. For the National Weather Service's Sky Harbor Airport station, in the center of the Phoenix urban region, $T_{1}$ and $T_{2}$ are $45.5^{\circ}$ and $43.3^{\circ} \mathrm{C}$, respectively. Table 1 lists the 10 EHEs identified for the Phoenix metropolitan region between 1961 and 2008 plus their highest recorded maximum and minimum temperatures.

Another potential indicator of an EHE is the number of consecutive days characterized by high nighttime temperatures (Karl and Knight 1997). Some of the EHEs derived from criteria 1-3 are also distinguished by exceptionally high nighttime temperatures of up to $35.6^{\circ} \mathrm{C}$. The highest daytime temperatures were recorded on 26 June $1990\left(50^{\circ} \mathrm{C}\right)$ and 28 July $1995\left(49.5^{\circ} \mathrm{C}\right)$, while the highest nighttime temperatures were observed on 15 July $2003\left(35.6^{\circ} \mathrm{C}\right)$ and 22 July $2006\left(35^{\circ} \mathrm{C}\right)$. The threshold temperatures $T_{1}$ and $T_{2}$ do not change significantly when the period of interest is expanded to 1961-2008.

The four most recent EHEs occurred during the North American monsoon (NAM) (Adams and Comrie 1997). NAM conditions, which generally occur during July and August, are characterized by deep southeasterly or southerly winds that transport moisture from the Gulf of
Mexico and the tropical eastern North Pacific into the region leading to widespread thunderstorm activity. The transport of moisture is due in large part to the position of the Bermuda high, which is typically centered over the Caribbean during the NAM. The moisture is transported by the southeasterlies on the western flank of the high. For each of the cases considered in this study, the high pressure was displaced west and north relative to the typical location during the NAM. Figure 1 shows the 500-hPa heights, obtained from the National Centers for Environmental Prediction (NCEP) Final Operational Global Analysis data that are available with a $1^{\circ}$ resolution at every $6 \mathrm{~h}$. For each EHE the center of the 500-hPa high was located over Arizona and the southwestern United States. The amplitude of the highs was reinforced by long-wave troughs over the Pacific Ocean.

The position of the high pressure shown in Fig. 1 is similar to that which occurs during the early, dry part of the summer (late May-June). While the daytime high temperatures are generally higher during June than during the NAM, the extreme heat events are more likely to occur after the NAM has begun but is temporarily suppressed (see Table 1). Subsidence associated with the high pressure adds to the warming and suppresses convection in all cases, which amplifies the daytime maximum temperature. In addition, the moisture content is generally higher during the NAM periods, even if the NAM is temporarily suppressed. This contributes to higher nighttime temperatures through increasing the downward flux of longwave radiation compared to the generally drier June atmosphere. In each of the cases, the EHE ended when the long wave trough moved through and displaced the high eastward. The absence of the subsidence warming and increased convection contributed to lower temperatures.

\section{b. Land use/land cover data and physical parameters}

Landsat-based 12-category LULC data (30-m pixels) for 1973, 1985, 1998, and 2005 were analyzed using the procedure of Stefanov et al. (2001). The data were incorporated into WRF by converting to the 33-category U.S. Geological Survey (USGS) Land Use/Land Cover System (Anderson et al. 1976) used in WRF (Fig. 2).

The Noah UCM as incorporated in WRF includes three urban land use classes characterized as commercial, high-intensity, and low-intensity residential. Here these have been adjusted: commercial-industrial, urban mesic residential and urban xeric residential, which are distinguished by the type of vegetation and irrigation (no vegetation, well-watered flood or overhead sprinkler irrigated, and drought-adapted vegetation with drip irrigation, respectively). 


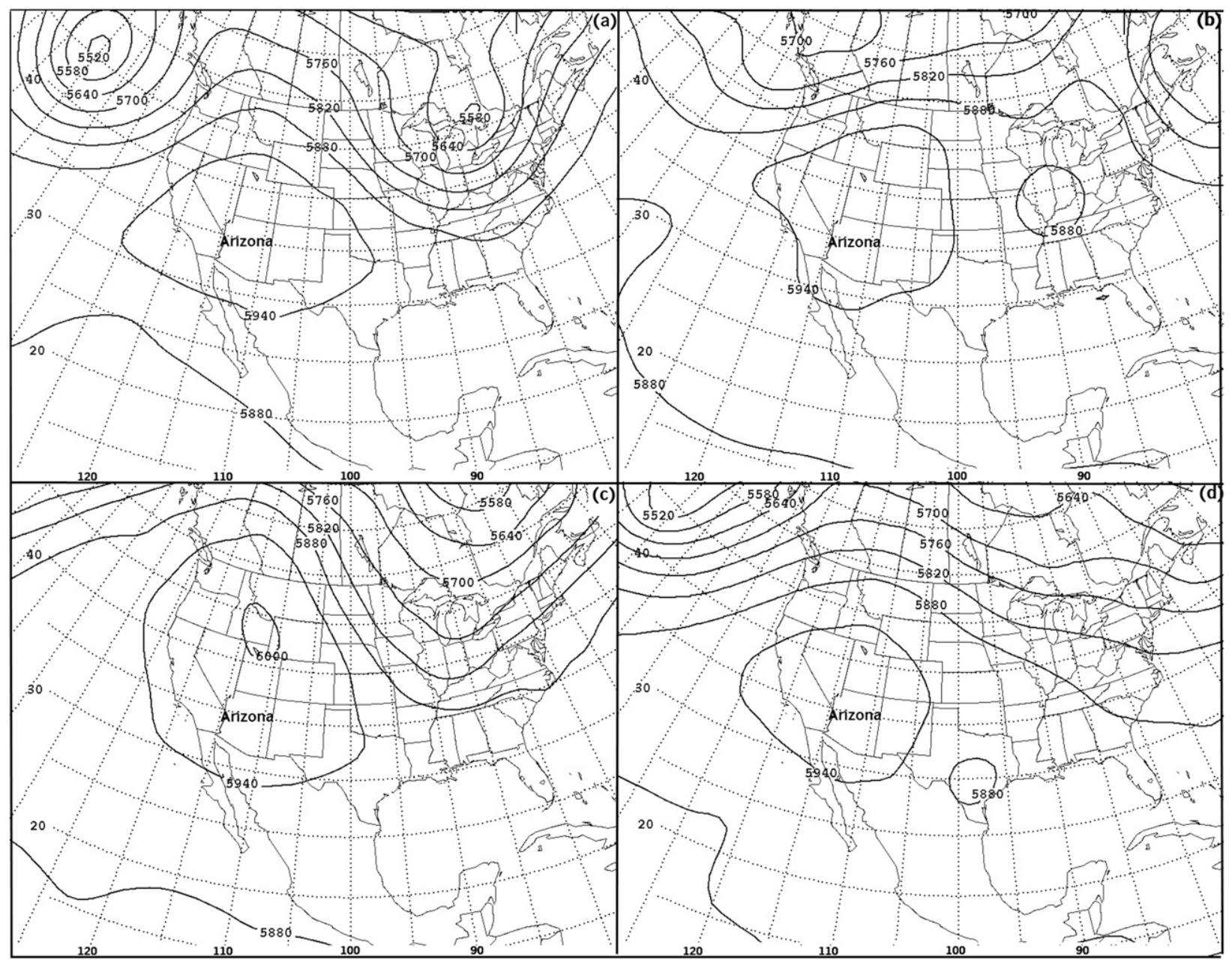

FIG. 1. Contours of 500-hPa heights (m) at 0000 UTC for (a) 12 Jul 2003, (b) 13 Jul 2005, (c) 22 Jul 2006, and (d) 04 Jul 2007 . The $x$ axis and $y$ axis are longitude $\left({ }^{\circ} \mathrm{W}\right)$ and latitude $\left({ }^{\circ} \mathrm{N}\right)$, respectively.

As described in detail in Grossman-Clarke et al. (2005) we adjusted the urban fraction according to detailed vegetative cover measurements that were obtained from an extensive field survey carried out in $30 \mathrm{~m} \times 30 \mathrm{~m}$ field plots at 200 randomly selected sites across the entire urban area (Survey 200; Hope et al. 2003). Development across the Phoenix area is largely suburban in nature, with an urban core of very limited spatial extent, unlike many older cities in more temperate regions. The fraction of the surface cover types in the residential urban categories is remarkably uniform across the entire metropolitan area. The fractional cover of built, vegetation, and soil surfaces comprises $0.73,0.10$, and 0.17 in the xeric residential and $0.60,0.23$, and 0.17 in the mesic residential categories, respectively. The building morphology is very similar in the residential classes with average building heights, roof and road widths of 6,10 , and $15 \mathrm{~m}$.

The commercial-industrial category is comprised almost entirely of anthropogenic surfaces (fractional cover of built surfaces 0.95 ). The average building height of commercial and industrial buildings is $10 \mathrm{~m}$. The large variation in road width $(10-100 \mathrm{~m})$ and building area complicates the assignment of building geometry. Here for the commercial-industrial class the building width $(10 \mathrm{~m})$ and street width $(10 \mathrm{~m})$ of the "commercial" land use class provided with WRF's urban parameter table (version 3.0.1.1) were applied. Similarly, the WRF standard values for heat capacity, conductivity, albedo, emissivity roughness length for heat and momentum of roof, road, and wall surfaces were used.

An anthropogenic heat flux $Q_{F}$ can be activated that is added to the sensible heat fluxes of road, roof, and wall surfaces, which form the total urban canopy sensible heat flux. We replaced the standard WRF values with Phoenix data derived by the Sailor and $\mathrm{Lu}$ (2004) method. Hourly $Q_{F}$ values are based on the monthly energy consumption and average vehicle kilometers traveled per person. The average energy and fuel consumption data are spatially 

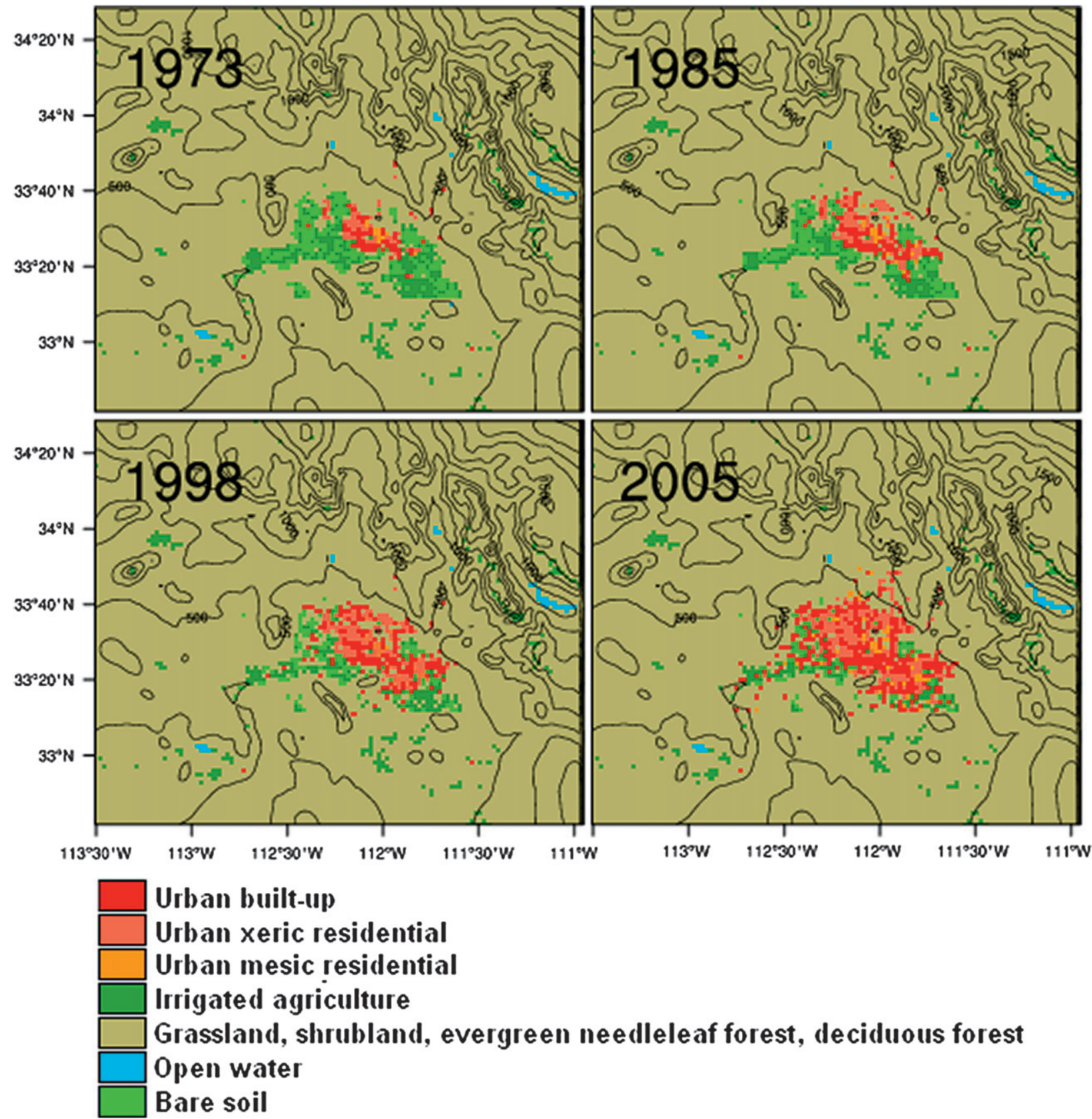

\section{Urban built-up}

Urban xeric residential

Urban mesic residential

Irrigated agriculture

Grassland, shrubland, evergreen needleleaf forest, deciduous forest

Open water

Bare soil

FIG. 2. Topography (contours from 0 to $3000 \mathrm{~m}$; interval $250 \mathrm{~m}$ ) and LULC for 1973, 1985, 1998, and 2005. Produced by WRF's preprocessing system for the inner modeling domain $(2 \times 2 \mathrm{~km}$ grid resolution $)$ based on Landsat satellite-derived LULC data and three urban LULC classes. To emphasize the urban land use changes the colors are grouped together for the rural land use classes (grassland, shrubland, deciduous broadleaf forest, evergreen needle leaf forest).

and temporally allocated based on the spatial distribution of the working and residential population densities (Grossman-Clarke et al. 2005). For this particular urban area, which is mostly suburban and not very densely settled, $Q_{F}$ values are small in comparison to the other heat fluxes. Maximum values for the built-up urban, xeric, and mesic residential areas are $\sim 30,35$, and $20 \mathrm{~W} \mathrm{~m}^{-2}$ and occurred during the evening rush hour (1700 LST) (Grossman-Clarke et al. 2005). Values during other daytime hours are between 5 and $25 \mathrm{~W} \mathrm{~m}^{-2}$.

There has been an increase in urban land use over time at the expense of agricultural and desert land use (Fig. 2). The predominant rural LULC category is shrubland, which represents desert vegetation in the 
USGS classification. The bare soil category in the region represents temporarily fallow farmland, that is, between crops. The land use data for the region including the agricultural areas were derived from satellite images acquired in early May 1973, 1985, and 1998 and March 2005. The combined bare soil and irrigated agricultural categories (Fig. 2) amount to the total cropland in the region. The latter agrees well with National Agricultural Statistics Service (NASS) data for Maricopa County where Phoenix is located. According to NASS, the major crops in the county are wheat (December through May), forage crops such as alfalfa (year round), and cotton (May through September). Cotton is planted in April and reaches full canopy cover in July with leaf area indices of $\sim(3-4) \mathrm{m}^{2} \mathrm{~m}^{-2}$ (Kimball et al. 1994). Alfalfa's leaf area index can be as high as $10 \mathrm{~m}^{2} \mathrm{~m}^{-2}$ (McAdam and Barta 2007). Additionally a significant amount of land is used for orchards (oranges, grapefruit) and vegetable growth year-round. The land use data derived from the May images characterize the forage crops as irrigated agriculture, while senescent wheat, emerging cotton, and temporarily unfarmed fields are classified as bare soil. To quantify the typical amount of barren and cultivated agricultural fields in Maricopa County during July (when the heat waves occurred) the area of irrigated cropland used for summer crops (cotton, alfalfa, corn) grown in Maricopa County for the years 1973-2005 (NASS) was compared with the total cropland (census of agriculture for Maricopa County). In Maricopa County the ratio of irrigated farmed to total cropland for July 1973-2007 varied between 0.50 and 0.73 , with the majority of years having a higher cover of irrigated use. July satellite images of the region indicate a highly heterogeneous pattern of barren and cultivated fields. Instead of manipulating the land use data, the Noah Land Surface Model (LSM) was applied to the bare soil category as though it was an irrigated agricultural land use category but with the following changes. The vegetation cover was adjusted to achieve a total crop cover of 0.70 in Maricopa County for each simulated year (green vegetation fractions of 0.42 , $0.40,0.35$, and 0.35 for $1973,1985,1998$, and 2005, respectively) while keeping the initial soil water content of the first soil layer at the climatological soil moisture content from the NCEP Eta Model to simulate soil evaporation for fallow fields.

\section{c. Numerical simulations}

WRF version 3.0.1.1 was employed with the adjustments to urban land use (section 2b). The urban canopy model (Kusaka and Kimura 2004) is applied to the fraction of the model grid cell with built cover, and the Noah LSM (Chen et al. 1997) is applied to the fraction of natural surfaces (vegetation, water, soil). The grid turbulent heat and radiation fluxes are the sum of the areally weighted fluxes for the surface types.

To sustain landscape vegetation in Phoenix, irrigation is necessary for most months of the year. However, the standard Noah LSM does not account for irrigation in the soil water content but assumes a climatological soil moisture content as obtained from WRF's initial conditions. The Noah LSM soil model has four layers with thicknesses of $0.05,0.25,0.70$, and $1.50 \mathrm{~m}$. For urban vegetation, as well as irrigated agricultural land, the soil moisture content was adjusted in WRF to the reference soil moisture that corresponds to field capacity. The predominant soil categories in the region are "sandy loam" and "loam," with field capacities of 0.383 and $0.329 \mathrm{~m}^{3} \mathrm{~m}^{-3}$ and wilting points of 0.047 and $0.066 \mathrm{~m}^{3} \mathrm{~m}^{-3}$. In the course of the simulations the soil moisture content for the sandy loam dropped to $0.35,0.36$, and $0.32 \mathrm{~m}^{3} \mathrm{~m}^{-3}$ for soil layer 1 to 3 and stayed at field capacity for layer 4. Plants did not experience significant water stress. In comparison the climatological soil moisture content as obtained from the NCEP Eta Model initial data are 0.10, 0.11, 0.12, and $0.14 \mathrm{~m}^{3} \mathrm{~m}^{-3}$ with little variation over the four simulated years. In WRF the root depth of the urban and agricultural vegetation extends to $1 \mathrm{~m}$ (layer 3 ). To account for subsurface drip irrigation and to avoid evaporation from bare soil surfaces that are usually dry, the initial soil moisture content was increased for the three subsurface layers for the urban land use categories but not for the top soil layer. For the irrigated agricultural category the soil moisture content was increased for all soil levels.

The Noah UCM incorporates urban geometry into the surface-energy balance and wind shear calculations. The urban geometry is characterized by a generic twodimensional street canyon that represents the effects of canyon heat distribution, shadowing from buildings, and reflection of radiation in the canopy layer. A multilayer heat conductivity equation is solved for roof, wall, and road temperature profiles. The UCM calculates sensible heat fluxes from roof, wall, and road and then aggregates them into the total sensible heat flux between the urban surface and the atmosphere.

Simulations were conducted for four EHEs during the last decade (Table 1), that is, for 12-16 July 2003, 12 17 July 2005, 21-24 July 2006, and 3-7 July 2007. The simulations for each EHE were carried out with the LULC data for 1973, 1985, 1998, and 2005 as well as with an idealized situation of no landscape irrigation in the urban area; that is, a total of 20 runs.

Each WRF run was started at 0000 UTC (1700 LST) allowing 24 overlapping hours for model spin up for 72-h simulation periods. Two-way nested WRF model runs with four domains and resolutions of 54, 18,6 , and $2 \mathrm{~km}$, respectively, were performed. In the simulations, 41 vertical 


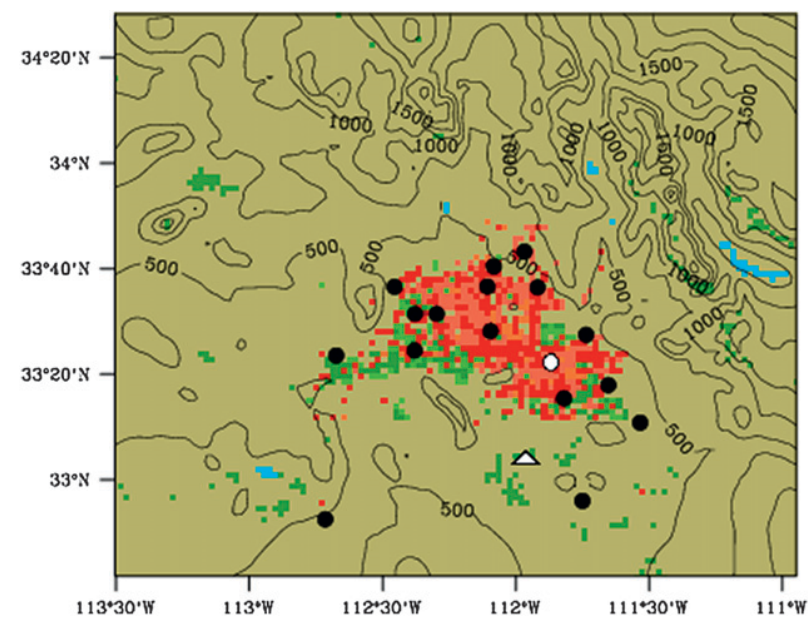

FIG. 3. Surface stations (dots and triangle) that were used for model evaluation located on the 2005 LULC and topography contours (from 0 to $3000 \mathrm{~m}$; interval $250 \mathrm{~m}$ ). See Fig. 2 for LULC class key. The locations of the NWS station at Sky Harbor Airport and a rural reference site at Maricopa are marked by a white dot and a white triangle, respectively.

levels were used with the first five vertical levels of approximately $25,35,45,60$, and $80 \mathrm{~m}$ AGL. The innermost domain included the Phoenix metropolitan area, surrounding desert, and agricultural land. Initial and boundary conditions were provided by the NCEP Eta grid $212(40-\mathrm{km}$ resolution) analysis. Every $3 \mathrm{~h}$ the lateral boundary conditions were updated from the ETA analysis. PBL processes were included via the MellorYamada-Janjic scheme (Janjic 2002), microphysics through the WRF Single-Moment 3-class simple ice scheme (Hong et al. 2004), convection for the domains with $54-$ and $18-\mathrm{km}$ resolutions by the Kain-Fritsch scheme (Kain 2004), and the long- and shortwave radiation processes were included through the Rapid Radiative Transfer Model (Mlawer et al. 1997) and Dudhia scheme (Dudhia 1989), respectively.

\section{d. Data for model evaluation}

To evaluate WRF, observations from 18 surface weather stations in the urban and surrounding areas were used. Figure 3 shows 2005 LULC data and station locations for the inner modeling domain. Ten stations are maintained by the National Weather Service (NWS). The data are available from the Global and United StatesIntegrated Surface Hourly dataset of the National Oceanic and Atmospheric Administration's National Climatic Data Center (http://www.ncdc.noaa.gov/oa/ncdc.html). The available hourly-observed air temperatures at $2 \mathrm{~m}$ AGL $T_{2 \mathrm{~m}}, 10 \mathrm{~m}$ AGL wind speed $V_{10 \mathrm{~m}}$, and wind direction are a 5-min average logged $15-10 \mathrm{~min}$ before the hour. The dataset also includes daily minimum and maximum temperatures. If the latter temperatures occurred at times other than at the $5 \mathrm{~min}$ before the hour they sometimes were slightly lower or higher than the minimum and maximum hourly temperatures. The LULC category for the location of eight of the NWS stations was classified by WRF as urban. Two locations (Gila Bend and Casa Grande) were classified as desert LULC (category 8). The eight Arizona Meteorological Network (AZMET; http://ag.arizona.edu/AZMET/index.html) stations used in the evaluation consist of four located within agricultural areas or placed at golf courses within the urban area in 2005; two stations are located in areas classified as mesic residential and collect data that are characteristic of areas with irrigation applied to a golf course; and two stations are in areas classified as xeric residential, which, however, was not their microscale characteristics (which was similar to the other more extensively irrigated areas). In the latter case, the classification is expected to result in an overestimation of temperatures by WRF. Misclassification can arise from the geographical reprojection of the land use data, selection of the dominant LULC for the USGS dataset, and low model resolution. The recorded AZMET $T_{2 \mathrm{~m}}, V_{10 \mathrm{~m}}$, and wind direction are hourly averages.

\section{Results and discussion}

\section{a. Model evaluation for periods of interest}

To evaluate WRF's performance for the four EHEs, simulated hourly $T_{2 \mathrm{~m}}, V_{10 \mathrm{~m}}$, and wind direction were compared with observations from 18 urban and surrounding areas surface weather stations. In WRF, $T_{2 \mathrm{~m}}$ is diagnosed by means of

$$
\begin{aligned}
T_{2 \mathrm{~m}} & =T_{s}-\frac{H}{\rho c_{p} C_{H}}, \\
C_{H} & =\frac{\kappa \times u_{*, 2 \mathrm{~m}}}{\ln \left(\frac{2 \mathrm{~m}}{z_{0, T}}\right)-\psi_{H}},
\end{aligned}
$$

where $\rho$ and $c_{p}$ are the air density and heat capacity of the air, respectively; $\kappa=0.4$ is von Kármán's constant; $z_{0, T}$ is the roughness length for heat; $\psi_{H}$ is the integrated universal function for heat; and $u_{*, 2 \mathrm{~m}}$ represents the friction velocity at $2 \mathrm{~m}$. The surface temperature $T_{s}$ and sensible heat flux $H$ are calculated as the weighted average of their values for the urban and rural fraction of cover of a model grid cell:

$$
\begin{aligned}
T_{s} & =T_{s, \text { urban }} \operatorname{frac}_{\text {urban }}+T_{s, \text { rural }}\left(1-\operatorname{frac}_{\text {urban }}\right) \text { and } \\
H & =H_{\text {urban }} \operatorname{frac}_{\text {urban }}+H_{\text {rural }}\left(1-\operatorname{frac}_{\text {urban }}\right) .
\end{aligned}
$$




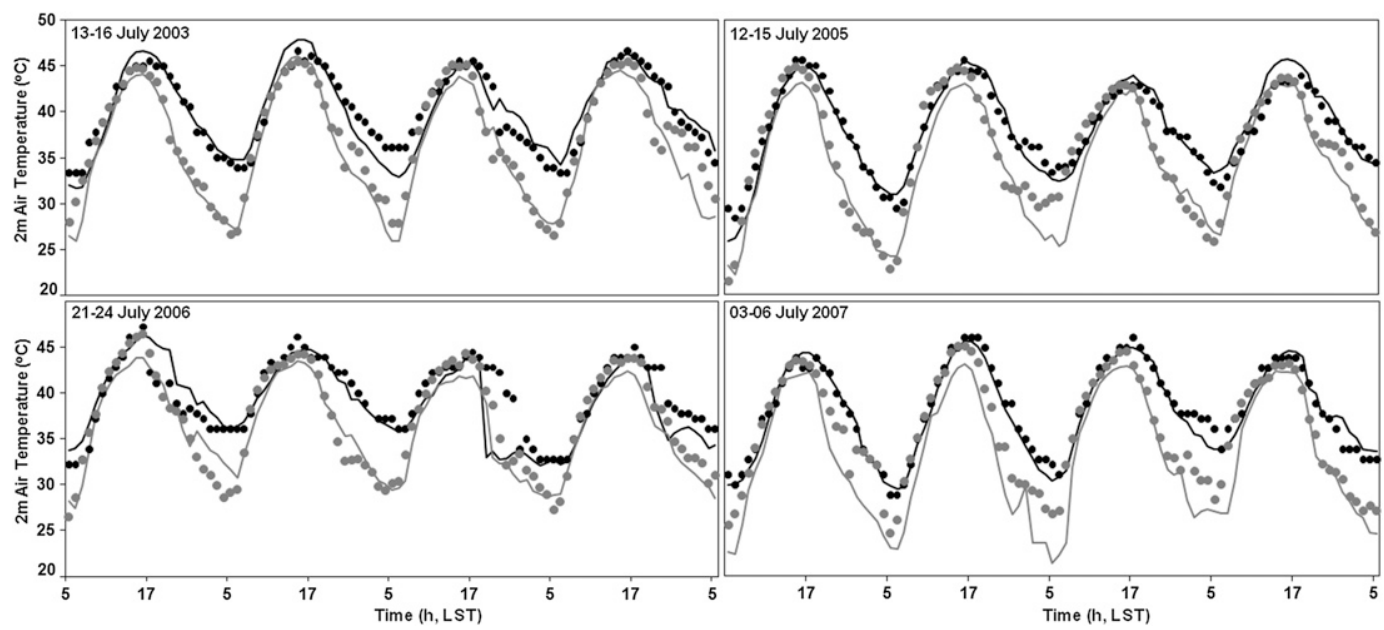

FIG. 4. Simulated and observed air temperatures at $2 \mathrm{~m}$ AGL at the Sky Harbor Airport NWS station (urban, observed: black dots; simulated: black line) and at the AZMET Maricopa station (rural, observed: gray dots; simulated: gray line) for four EHEs. Data are for 13-16 Jul 2003, 12-15 Jul 2005, 21-24 Jul 2006, and 3-6 Jul 2007.

The fraction cover of anthropogenic surfaces (buildings and roads) in a model grid cell is called frac urban$_{\text {, while the }}$ rural cover fraction (vegetation, soil, water surfaces) is then $\left(1-\right.$ frac $\left._{\text {urban }}\right)$. The $10-\mathrm{m}$ wind speed is determined diagnostically by means of Monin-Obukhov similarity theory under consideration of the atmospheric stability from the simulated temperatures at ground level and simulated temperatures and components of horizontal wind speed at the first prognostic level.

Figure 4 shows the simulated and observed $T_{2 \mathrm{~m}}$ for the Sky Harbor Airport station (Fig. 3 white dot). The simulations capture the diurnal variation including minimum and maximum temperatures for much of the period of each EHE within $2 \mathrm{~K}$ of the observed $T_{2 \mathrm{~m}}$. On day 3 of the 2006 EHE a mesoscale front reached the urban area about $3 \mathrm{~h}$ earlier in the simulation than was observed, leading to a premature sudden drop in simulated temperature.

At most times WRF captured the recorded air temperatures for a rural reference site at the University of Arizona's Maricopa Agricultural Center (Fig. 3 white triangle, AZMET station, $361 \mathrm{MSL}$ ) well. An underestimation of maximum daytime (up to $3 \mathrm{~K}$ ) and minimum nighttime temperatures (up to $5 \mathrm{~K}$ ) occurred on some days. This behavior could be caused by the presence of an Irrigation Laboratory Building in close vicinity to the station and cultivation of crops in its surrounding. Interestingly the observed maximum daytime temperatures between the two stations differed slightly while the nighttime temperatures were consistently significantly higher in the urban area. For the two stations, the average urban rural difference in minimum nighttime temperatures was $6 \mathrm{~K}$ for the four EHEs examined, with the maximum difference of $8.2 \mathrm{~K}$ on 15 July 2003.
To evaluate the regional model performance the average simulated and observed $T_{2 \mathrm{~m}}, 10-\mathrm{m}$ wind speeds and direction between all 18 stations differentiated between rural (6 stations) and urban stations (12 stations) are compared for each EHE (Figs. 5a-c). The overall agreement in $T_{2 \mathrm{~m}}$ for both urban and rural land use is good for all EHEs (Fig. 5a). Figure 5 also includes the statistical measures bias, root-mean-square error (RMSE) and standard deviation of the error (SDE) for each hour of the day for the four simulation periods for all 18 stations. The observed data were subtracted from the simulated data. The bias of $T_{2 \mathrm{~m}}$ at most times was $\pm 2 \mathrm{~K}$ with no obvious tendency for over- or underestimation. For the years 2003, 2005, and 2006, the RMSE and SDE were between 1 and $3 \mathrm{~K}$, except for some hours, when larger RMSE values occurred, which corresponded to larger deviations between simulated and observed data. For the nighttime hours of the year 2007 relatively larger RMSE and SDE values of up to 5 and $4 \mathrm{~K}$ occurred indicating a larger spread of the differences of simulated and observed data.

The overall agreement between simulated and observed $V_{10 \mathrm{~m}}$ is good (Fig. 5b); however, there was a tendency for WRF to not always capture the peak average wind speeds of $\sim 7 \mathrm{~m} \mathrm{~s}^{-1}$ as observed at the urban stations. A possible reason could be the location of eight of the urban stations at airports which is accompanied by relatively low surface roughness in close proximity of the stations. Except for 2006, there is also a tendency to overestimate the wind speeds for the rural stations. The bias for $V_{10 \mathrm{~m}}$ is mostly within $\sim \pm 2 \mathrm{~m} \mathrm{~s}^{-1}$, while RMSE and SDE amount to $\sim(1$ to 3$) \mathrm{m} \mathrm{s}^{-1}$.

Typical high pressure, clear-sky nighttime flow in the Phoenix valley consists of down-valley winds that originate 
on the large-scale terrain to the north and northeast. During daytime predominantly westerly anabatic winds occur. The results for wind direction (Fig. 5b) show that WRF captures the reversal in flow direction for most days in 2003, 2005, and 2007 well for both urban and rural stations. During 2006 the typical flow pattern is not clearly established, and the simulated wind direction deviates at times considerably from the observed data. With values of $\sim \pm 50^{\circ}$ for bias, $50^{\circ}-100^{\circ}$ for SDE and RMSE for most hours of the day the model captures wind direction reasonably well.

Overall the results suggest that the modeled regional near-surface variables are represented sufficiently well to conduct the sensitivity analysis to investigate the influence of historical land use changes on intensity and spatial extent of the EHEs.

\section{b. Influence of historical land use changes on near-surface air temperature}

To investigate the contribution of historical land use changes to extreme temperatures in the Phoenix region, simulations were conducted for each EHE with four sets of land use data: 1973, 1985, 1998, and 2005. Differences in simulated $T_{2 \mathrm{~m}}$ between the land use scenarios were used as a measure of LULC effects on regional nearsurface air temperature. Here the focus is on the maximum and minimum daily air temperatures as they are a measure of the intensity of an EHE. The magnitude of temperature changes varied by EHE and for different days during each EHE. To illustrate the effects of land use changes on minimum and maximum daily temperatures over time, the effects were averaged over the 18 simulated days that constituted the four EHEs. Difference maps allow comparison between the regional $T_{2 \mathrm{~m}}$ simulated with the 2005 LULC to the $T_{2 \mathrm{~m}}$ obtained with the 1973 , 1985, and 1998 LULCs at 0500 and 1700 LST 2005, respectively (Fig. 6). Based on the simulations, new urban development caused an intensification and expansion of the area experiencing extreme temperatures. As expected, the most recent (1998) with the shortest time for LULC changes (since 2005) show the smallest but still detectable differences.

For the minimum temperatures (0500 LST), Fig. 6 shows that with urban development in formerly agricultural as well as desert areas the temperatures increased on average by 5-8 K, leading to an expansion of the area experiencing elevated nighttime temperatures. The largest changes in minimum nighttime temperatures occur in the center of the formerly agricultural areas to the southeast of Phoenix and amounted for some nights to $\sim 10 \mathrm{~K}$. Smaller changes in minimum $T_{2 \mathrm{~m}}$ of 4-6 K are detected when desert land underwent the transformation to urban land use. Nighttime temperatures in the existing urban core show only relatively small changes of up to $1-2 \mathrm{~K}$ with the ongoing LULC changes. The reduction of advection of cooler air from formerly agricultural areas could be one possible cause for the increase in temperature in the existing urban core. Comparing changes in minimum temperatures between land use scenarios showed that strong changes in $T_{2 \mathrm{~m}}$ were relatively localized where new urban development took place. The expansion of the built-up area also increased minimum temperatures in the previously developed fringe region by $1-3 \mathrm{~K}$, as in the center of the metropolitan region. This corresponds well to Brazel et al.'s (2007) analysis of Phoenix metropolitan region changes in observed June mean minimum 2-m air temperatures over time; they found $T_{2 \mathrm{~m}}$ depends on synoptic conditions, location in an urban development zone (fetch) and pace of building construction within $1 \mathrm{~km}$ of the weather station.

Daytime temperatures (1700 LST) are less affected when urban development replaces desert as maximum daytime $T_{2 \mathrm{~m}}$ changed by $\sim 1 \mathrm{~K}$ (Fig. 6 , lower). In the urban center, the increase over time in $T_{2 \mathrm{~m}}$ amounted to about $0.5 \mathrm{~K}$. As the main conversion of agricultural to urban land use concluded in the mid-1990s the changes in average maximum $T_{2 \mathrm{~m}}$ between 1998 and 2005 were relatively small. However, when irrigated agricultural land was converted to suburban development, maximum $T_{2 \mathrm{~m}}$ increased on average by $2-4 \mathrm{~K}$.

Figure 7 shows simulated net all-wave radiation and latent, sensible, and ground heat flux for a grid cell with desert, irrigated agricultural, built-up urban, and urban mesic residential land use for 13-14 July 2003. The heat fluxes are positive when directed away from the surface into the atmosphere and negative when directed toward or into the surface as for the ground heat flux. The ground heat flux for the urban land use categories also accounts for the heat storage in roofs and walls.

Maximum daytime latent heat fluxes $\left(Q_{E}\right)$ for irrigated agriculture land are of the order of $500 \mathrm{~W} \mathrm{~m}^{-2}$ compared to about 20 and $75 \mathrm{~W} \mathrm{~m}^{-2}$ for commercial/ industrial and xeric residential areas (not shown), respectively. Mesic residential LULC does not have a significant regional effect despite simulated $Q_{E}$ of up to $350 \mathrm{~W} \mathrm{~m}^{-2}$ as is found in limited areas. Because of the low soil moisture content in the natural desert, $Q_{E}$ is simulated to be $\sim 20 \mathrm{~W} \mathrm{~m}^{-2}$. The magnitude of maximum daily sensible heat fluxes $\left(Q_{H}\right)$ was $\sim 100 \mathrm{~W} \mathrm{~m}^{-2}$ for irrigated agricultural, $\sim 450 \mathrm{~W} \mathrm{~m}^{-2}$ for desert, and $\sim 400 \mathrm{~W} \mathrm{~m}^{-2}$ for commercial-industrial areas. The increase in sensible heat fluxes with urban development led to the daytime warming when agricultural land was replaced with urban development. Because of the large 
(a)

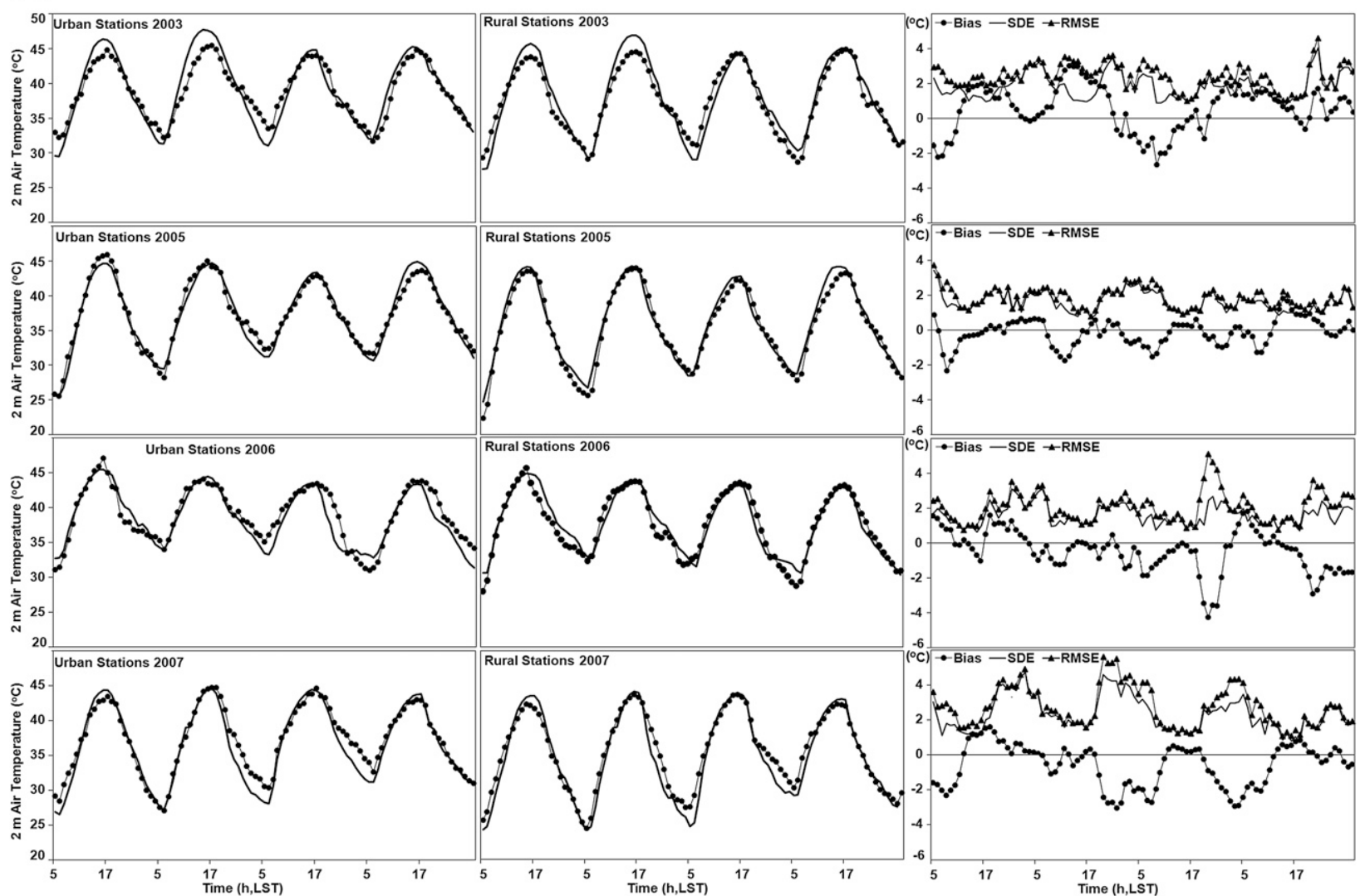

FIG. 5. Observed (dots) and simulated (line) for (a) $2 \mathrm{~m}$ AGL air temperatures, (b) $10 \mathrm{~m}$ AGL wind speed, and (c) $10 \mathrm{~m}$ AGL wind direction averaged for 6 rural and 12 urban stations for each EHE as well as statistical measures bias, RMSE and SDE for all 18 stations: 13-16 Jul 2003, 12-15 Jul 2005, 21-24 Jul 2006, and 3-6 Jul 2007.

daytime heat-storage flux for the commercial-industrial category during the hours before noon of up to $\sim-450$ $\mathrm{W} \mathrm{m}{ }^{-2}$, the simulated $Q_{H}$ for the desert areas is larger than for the urban area. This supports results of a study by Brazel et al. (2000) on the effects of urban development and population growth in the Phoenix region for the period 1910-95 on mean minimum and maximum air temperatures. They did not find a significant increase in average maximum June daytime air temperatures after $\sim 1940$ in the center of the urban area and on average slightly higher maximum daytime temperatures at a rural desert site.

During summer the agricultural areas are usually the coolest in the region during day and night. Reasons for this are 1) that plant cover in agricultural areas reduces the amount of absorbed solar radiation and subsequently heat storage in the agricultural soils and 2) irrigation. Because of flood irrigation the bare soil in agricultural fields is usually moist. However, evaporation reduces heat storage relative to desert soils even though the albedo of moist soils is lower and heat capacity higher.
For most parts of the year desert soil is dry and therefore has larger heat storage. The ground heat flux of the two land use categories is similar during day- and nighttime (Fig. 7). During nighttime, the $Q_{H}$ for irrigated agricultural LULC is $\sim-75 \mathrm{~W} \mathrm{~m}^{-2}$ indicating that surface temperature is lower than air temperature. Because of soil evaporation a positive nighttime $Q_{E}$ of $\sim 75 \mathrm{~W} \mathrm{~m}^{-2}$ is simulated.

For the urban land use categories the nighttime net radiation amounts to $\sim-200 \mathrm{~W} \mathrm{~m}^{-2}$ leading to a warming of the atmosphere in the city. With maximum values of $\sim 150 \mathrm{~W} \mathrm{~m}^{-2}$ the ground heat flux for the commercial/ industrial category is significantly higher than for the other land use types.

Based on the simulations, we conclude that land use characteristics that evolved over the past 35 years in the Phoenix metropolitan region have had a significant impact on near-surface air temperatures occurring during EHEs in the area. Daytime temperatures are higher because of the conversion of agricultural to urban land use, which occurred in the first two decades of this rapid 
(b)



FIG. 5. (Continued)

urbanization (mid-1970s to mid-1990s). Land use changes in the past $\sim 15$ years include conversion of desert to urban land use, which has led predominantly to an increase in nighttime air temperatures.

From the simulations the area experiencing extreme daytime temperatures increased between the years 1973 and 2005 by $\sim 1000 \mathrm{~km}^{2}$ from $\sim 500$ to $\sim 1500 \mathrm{~km}^{2}$. This corresponds to the area that experienced a transition from irrigated agricultural to urban land use. The area lost the cooling effect of irrigation and is therefore now similarly hot as desert and previously urbanized areas. The area experiencing elevated nighttime temperatures increased by $\sim 1800 \mathrm{~km}^{2}$ from $\sim 500 \mathrm{~km}^{2}$ in 1973 to $2300 \mathrm{~km}^{2}$ in 2005 and includes the area that was transformed from formerly agricultural and desert into urban land use.

We assumed that building morphology of the urban core did not change significantly when assigning values to parameters in the LULC categories. Future urban development might lead to an increase in building density and building heights in the region by replacing the now largely suburban development with multistory buildings. This would potentially lead to local temperature changes that differ from these results. Future intensification and temporal expansion of EHE episodes is also possible because of global warming. Although the interactions of LULC changes and global climate change and their effect on the severity of summer EHEs in the region were not investigated here, it can be assumed that the region will be highly sensitive to any additional warming.

The role of landscape irrigation to cooling of the region during the EHE episodes is also of interest. City planners often focus on the tradeoffs between water use and cooling (Mitchell et al. 2008). Water is an increasingly limited resource in this arid region (Hirt et al. 2008), and therefore newer urban development is characterized almost exclusively by xeric landscaping (native plants with low vegetative cover fraction; see section $2 \mathrm{a}$ ). Additional WRF simulations were carried out for each EHE with the 2005 LULC data, with no landscaping and agricultural irrigation, and with WRF's standard urban vegetation category 5 (cropland-grassland mosaic) replaced with category 8 (shrubland) to represent native desert vegetation. The vegetation parameters, soil moisture content, and soil class parameters, which determine the plant's 
(c)
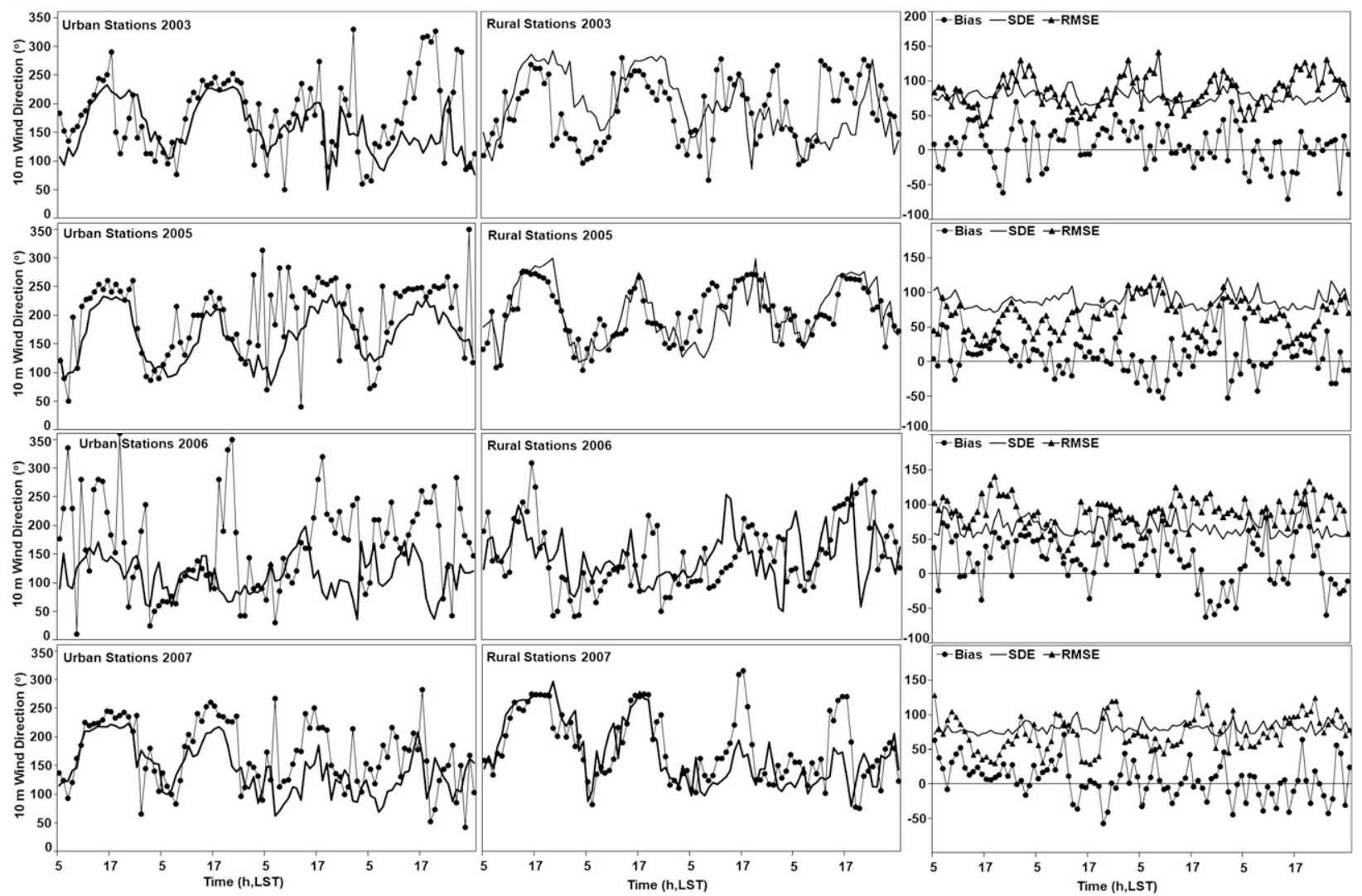

FIG. 5. (Continued)

ability to take up soil water for transpiration, are all impacted by the category change. Even with the low soil moisture content as supplied by WRF's initialization with the NCEP Eta Model the evapotranspiration rates for the standard urban vegetation were relatively high (up to $120 \mathrm{~W} \mathrm{~m}^{-2}$ ) and therefore unrealistic for the sparse desert vegetation (maximum $Q_{E} \sim 20 \mathrm{~W} \mathrm{~m}^{-2}$ ). The simulations showed subtle effects of irrigation on $T_{2 \mathrm{~m}}$ in most parts of the city. The removal of irrigation led to an average change (averaged over all days of the four EHEs) in daytime maximum and nighttime minimum temperatures of $0.5-1 \mathrm{~K}$.

Here the focus is on the regional-scale effects of the cooling potential of landscaping. Hence local-scale effects of irrigation on a subneighborhood scale might not be captured by the model (highest resolution: $2 \mathrm{~km}$ ), and that dominant land use is assigned (in the 30" USGS LULC dataset and to each model grid cell). It would potentially be worthwhile to test if using spatially explicit urban vegetation cover in each grid cell rather than the urban land use classes with their fixed vegetation fraction provides different results.
The influence of LULC changes on near-surface wind speed during the EHE episodes (Fig. 8) is of interest as increased urban roughness leads potentially to an increase in vertical momentum fluxes thereby reducing mean flow (Brown 2000). Urban development has led to a reduction of the already relatively weak nighttime winds by 1 to $2 \mathrm{~m} \mathrm{~s}^{-1}$ and therefore a reduction of advection of cooler air into the city (Fig. 8, upper). The afternoon (1700 LST) wind speeds are affected by land use changes in a larger region by $\sim(1-4) \mathrm{m} \mathrm{s}^{-1}$ (Fig. 8 , lower). This is mainly to the north and northeast of the city, which is in the direction of the predominant upslope flow. Further investigation is necessary to analyze if those effects result from thermodynamic or dynamic characteristics of the city or a combination of both. Under typical high pressure and clear-sky systems in the Phoenix valley, nighttime flow consists of downslope and down-valley winds that originate either on slopes surrounding the valley $(10-\mathrm{km}$ scale $)$ or on the large-scale terrain to the north (100-km scale). Gravity current fronts associated with the $10-\mathrm{km}$-scale flow reach the valley in early evening, whereas the fronts of the mesoscale flows arrive early in the 


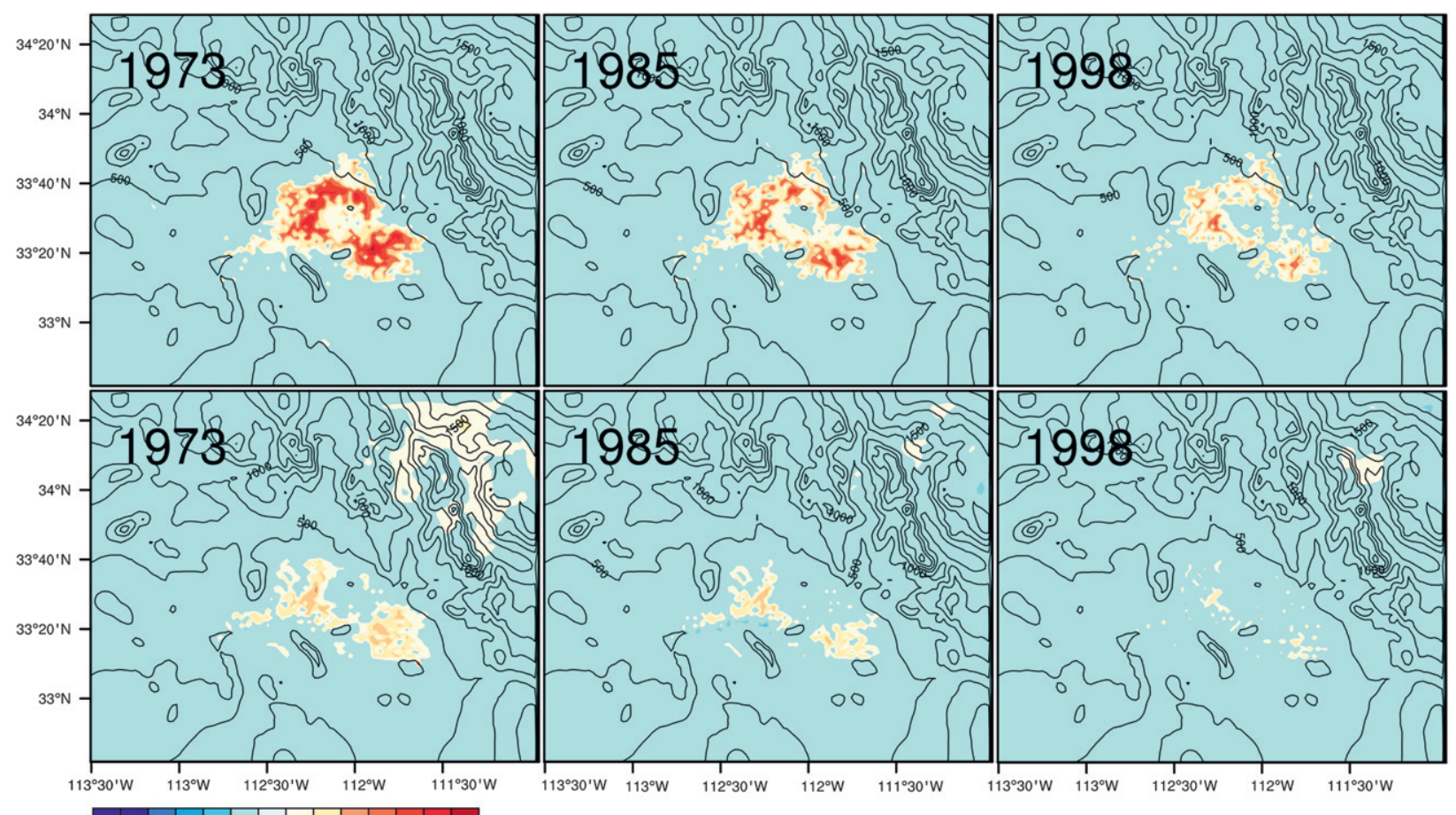

$\begin{array}{llllllllllllll}-5 & -4 & -3 & -2 & -1 & 0 & 1 & 2 & 3 & 4 & 5 & 6 & 7 & (\mathrm{~K})\end{array}$

FIG. 6. Average difference (18 simulated days of the considered EHEs) in air temperature $2 \mathrm{~m}$ AGL $\left(T_{2 \mathrm{~m}}\right)$ between $2005 \mathrm{LULC}$ and (left to right) historic LULC data 1973, 1985, and 1998) for (top) 0500 LST ( daily minimum temperatures) and (bottom) 1700 LST ( $\sim$ daily maximum temperatures). Also included are topography contours (from 0 to $3000 \mathrm{~m}$; interval $250 \mathrm{~m}$ ).

morning. During daytime the flow is reversed and heating of the air on the mountain slopes causes predominantly westerly anabatic winds. Characteristic surface wind speeds of the flows are about $1-5 \mathrm{~m} \mathrm{~s}^{-1}$. Further details of the diurnal circulation are described by Fernando et al. (2001).

\section{Summary and conclusions}

Here the potential contribution of LULC changes to daily minimum and maximum near-surface air temperatures, during four recent summer EHEs in the Phoenix
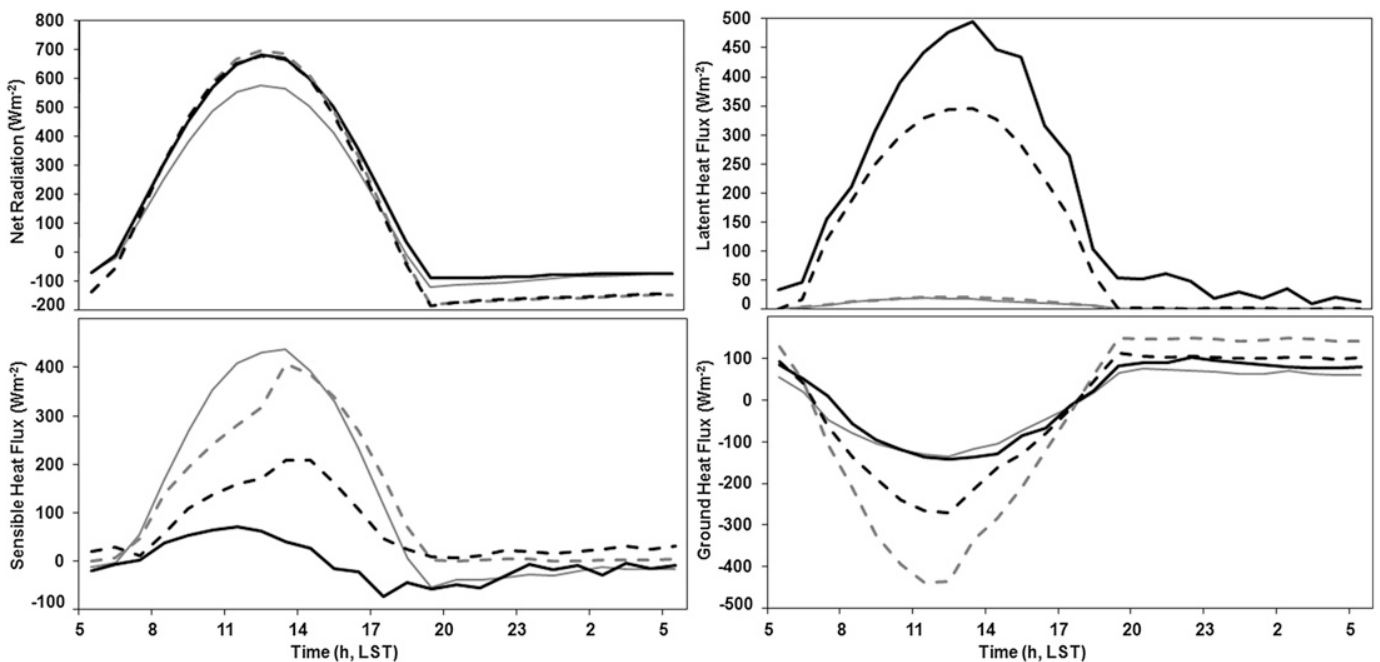

FIG. 7. Simulated (top left) net all-wave radiation and (top right) latent, (bottom left) sensible, and (bottom right) ground heat flux for grid cells with desert (gray line), irrigated agricultural (black line), urban commercial-industrial (gray dashed line), and urban mesic residential (black dashed line) LULC for 0500 LST 13 Jul 2003-0500 LST 14 Jul 2003. 


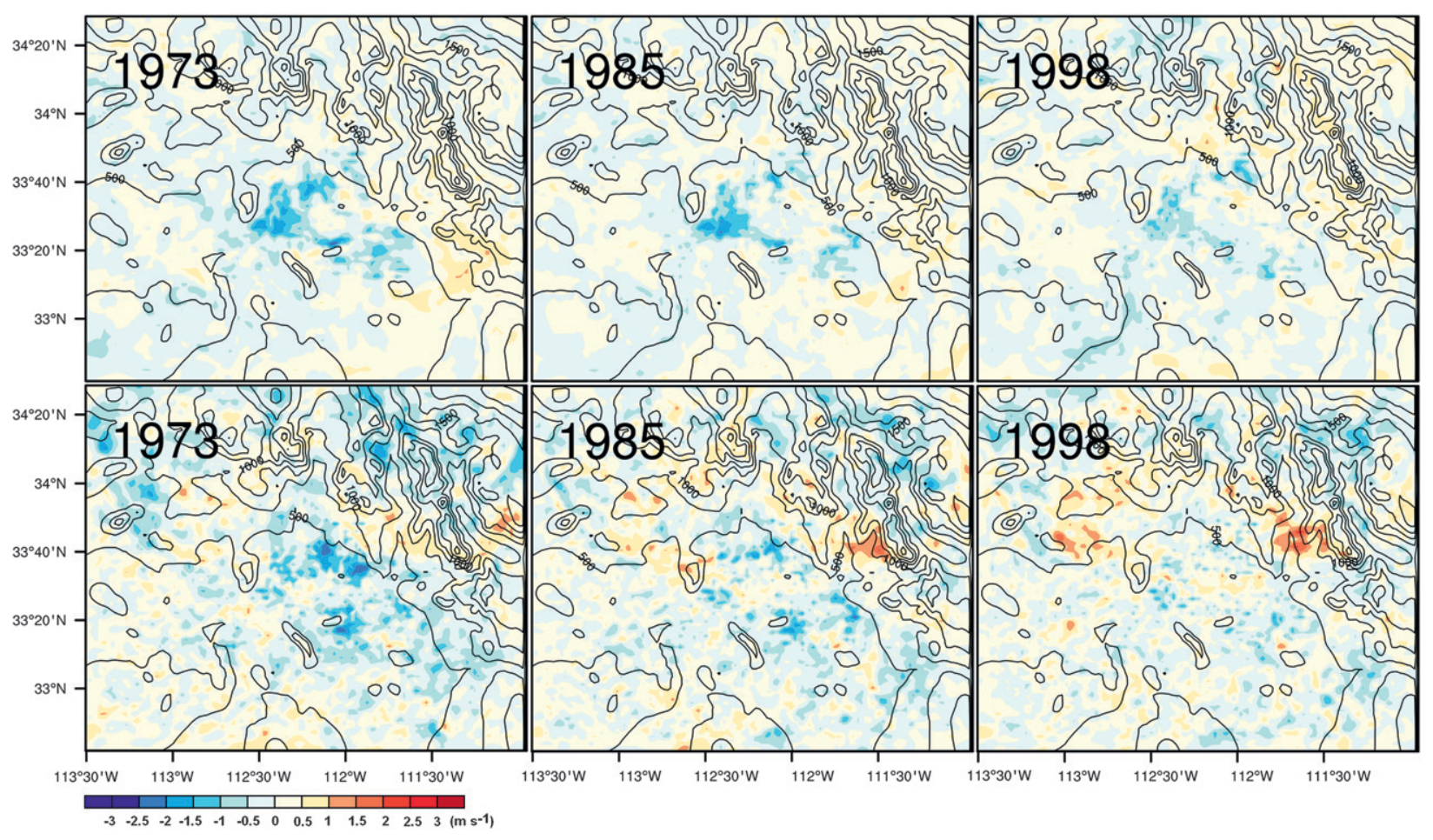

FIG. 8. As in Fig. 6 but for differences in $10 \mathrm{~m}$ AGL wind speed.

metropolitan area, are studied using WRF with Noah Urban Canopy Model and remotely sensed LULC data for 1973, 1985, 1998, and 2005. Simulations were carried out for each EHE with the four LULC datasets. Given the same synoptic conditions present during each of the EHEs, we have shown that the near-surface air temperatures would have been lower with precedent LULC.

Results show that urban land use characteristics that have evolved over the past $\sim 35$ years in the Phoenix metropolitan region have had a significant impact on extreme near-surface air temperatures occurring during EHEs in the area. Simulated maximum daytime and minimum nighttime temperatures were notably higher because of the conversion of agricultural to urban land use [by $\sim(2-4$ and $8-10 \mathrm{~K})$, respectively]. The conversion of desert to urban land use led to a significant increase in nighttime air temperatures $(6-7 \mathrm{~K})$ and slight increases in daytime temperatures of about $1 \mathrm{~K}$. Current landscaping irrigation contributes to cooling of those parts of the region that have extensive areas of mesic vegetation $(\sim 2 \mathrm{~K})$, but little benefit $(\sim 0.5 \mathrm{~K})$ is obtained from irrigation for the more extensive areas characterized with predominantly xeric residential and commercialindustrial land use.

These results agree well with Brazel et al. (2000) who found no significant increase in average maximum June daytime air temperatures after $\sim 1940$ in the center of the urban area and on average slightly higher maximum daytime temperatures at a rural site southeast of the Phoenix metropolitan region. They also found that the average June minimum nighttime temperatures were on average $5 \mathrm{~K}$ (maximum up to $\sim 10 \mathrm{~K}$ ) higher at the Phoenix Sky Harbor Airport in comparison to the rural site with a slight upward trend with the expansion of the urban area after 1950.

In this study our focus is on extreme daytime temperatures since increased deaths in Arizona correspond to those periods (Centers for Disease Control 2005). Another potential indicator of extreme heat events are high nighttime temperatures. The threshold temperatures $T_{1}$ and $T_{2}$ for the minimum nighttime temperatures are calculated to $32.8^{\circ}$ and $30.6^{\circ} \mathrm{C}$. When applying the Huth et al. (2000) criteria extremely high nighttime temperature events for the past decade were identified for 12-25 July 2003, 14-21 July 2005, and 12-24 July 2006. Those periods include the 2003 and 2006 EHEs as well as overlay partly with the 2005 EHE. Generally the events with extremely high minimum temperature last longer than the EHEs.

The largest values for the urban heat island (UHI) in the Phoenix region occur during the late spring and early summer before the onset of the NAM when humidity is generally very low (Brazel et al. 2000). For the years 2003, 2005, 2006, and 2007 the average UHI for 
the months of June and July amounts to 7 and $5 \mathrm{~K}$, respectively (based on the Maricopa AZMET and Sky Harbor Airport NWS data). EHEs were characterized frequently by larger UHIs than typical for the month of July, but UHIs were not elevated above values observed during June. For 2003 and 2006 the largest UHIs of the extreme nighttime temperature periods occurred during EHEs. The results of this study can therefore also give some insight in the magnitude of the contribution of historical LULC changes on minimum nighttime temperatures during periods when they are extremely high. However, further analysis is necessary to comprehensively investigate the contribution of LULC changes on extreme nighttime temperature events. In particular, further simulations over the whole period of those events are necessary to derive average results.

Increases in near-surface air temperature in Phoenix have potentially negative impacts on human comfort (Harlan et al. 2006) and cause an increase in the demand for energy use for air conditioning as well as degradation in air quality by increased ozone production (Nowak et al. 2000). Furthermore, elevated nighttime temperatures in Phoenix during the summer lead to elevated rates of plant dark respiration and the depletion of stored carbon within the plant causing growth of many plants to stop or plant dieback (Stabler et al. 2005).

The study shows that it is useful to complement historical land use change information, surface station data, and near-surface meteorological variables obtained from mesoscale meteorological models. A well-tested simulation model has limitations, like all methods, but provides a useful tool to understand complex interactions that underlie observed atmospheric responses. As in this study, mesoscale atmospheric models are increasingly being employed to improve understanding of processes related to regional- to neighborhood-scale climate and air quality. In recent years a better description of urban surface processes in mesoscale atmospheric models has been emphasized (Martilli 2007; Grimmond et al. 2009) and increasingly allows the application of mesoscale models for the analysis of meteorological processes and scenario simulations in urban areas.

Acknowledgments. This material is based upon work supported by the National Science Foundation under Grants ATM-0710631, DEB-0423704, Central ArizonaPhoenix Long-Term Ecological Research (CAP LTER), and GEO-0816168. Any opinions, findings, and conclusions or recommendation expressed in this material are those of the authors and do not necessarily reflect the views of the National Science Foundation.

\section{REFERENCES}

Adams, D. K., and A. C. Comrie, 1997: The North American monsoon. Bull. Amer. Meteor. Soc., 78, 2197-2213.

Anderson, J. R., E. E. Hardy, J. T. Roach, and R. E. Witmer, 1976: A land use and land cover classification system for use with remote sensor data. Geological Survey Professional Paper 964, U.S. Government Printing Office, 28 pp.

Brazel, A., N. Selover, R. Vose, and G. Heisler, 2000: The tale of two climates-Baltimore and Phoenix urban LTER sites. Climate Res., 15, 123-135.

— P. Pober, S. J. Lee, S. Grossman-Clarke, J. A. Zehnder, B. Hedquist, and E. Comparri, 2007: Dynamics and determinants of regional urban heat island change (1990-2004) within Metropolitan Phoenix, Arizona, USA. Climate Res., 33, 171-182.

Brown, M., 2000: Urban parameterizations for mesoscale meteorological models. Mesoscale Atmospheric Dispersion, Z. Boybeyi, Ed., WIT Press, 193-255.

Buyantuyev, A., 2005: Land cover classification using Landsat Enhanced Thematic Mapper (ETM) data-Year 2005. [Available online at http://caplter.asu.edu/data/?path=/exist/rest/db/ datasets/util/xquery/getDatasetById.xql?_xsl=/db/datasets/util/ xslt/datasetHTML.xsl\&id=knb-lter-cap.377.1.]

Centers for Disease Control, 2005: Heat-related mortalityArizona, 1993-2002, and United States, 1979-2002. Morbidity and Mortality Weekly Rep. 54, 628-630.

Chen, F., Z. Janjic, and K. Mitchell, 1997: Impact of the atmospheric surface-layer parameterizations in the new land-surface scheme of the NCEP mesoscale Eta model. Bound-Layer Meteor., 85, 391-421.

— - H. Kusaka, M. Tewari, J.-W. Bao, and H. Hirakuchi, 2004: Utilizing the coupled WRF/LSM/urban modeling system with detailed urban classification to simulate the urban heat island phenomena over the Greater Houston area. Extended $A b$ stracts, Fifth Conf. on Urban Environment, Vancouver, BC, Canada, Amer. Meteor. Soc., P9.11. [Available online at http:// ams.confex.com/ams/AFAPURBBIO/techprogram/paper_ 79765.htm.]

Cotton, W. R., and R. A. Pielke, 2007: Human Impacts on Weather and Climate. Cambridge University Press, $330 \mathrm{pp}$.

Dickinson, R. E., 2003: Framework for inclusion of urbanized landscapes in a climate model. Eos, Trans. Amer. Geophys. Union, 84 (Fall Meeting Suppl.), Abstract U51C-01.

Diffenbaugh, N. S., F. Giorgi, and J. S. Pal, 2008: Climate change hotspots in the United States. Geophys. Res. Lett., 35, L16709, doi:10.1029/2008GL035075.

Dudhia, J., 1989: Numerical study of convection observed during the Winter Monsoon Experiment using a mesoscale twodimensional model. J. Atmos. Sci., 46, 3077-3107.

Fernando, H. J. S., M. S. Lee, J. Anderson, M. Princevac, E. Pardyjak, and S. Grossman-Clarke, 2001: Urban fluid mechanics: Air circulation and contaminant dispersion in cities. Environ. Fluid Mech., 1, 107-164.

Grimmond, C. S. B., and Coauthors, 2009: Urban surface energy balance models: Model characteristics and methodology for a comparison study. Meteorological and Air Quality Models for Urban Areas, A. Backlanov et al., Eds., Springer-Verlag, 151-162.

Grossman-Clarke, S., J. A. Zehnder, W. L. Stefanov, Y. Liu, and M. A. Zoldak, 2005: Urban modifications in a mesoscale meteorological model and the effects on surface energetics in an arid metropolitan region. J. Appl. Meteor., 44, 1281-1297. 
Harlan, S. L., A. J. Brazel, L. Prashad, W. L. Stefanov, and L. Larsen, 2006: Neighborhood microclimates and vulnerability to heat stress. Soc. Sci. Med., 63, 2847-2863.

Hirt, P., A. Gustafson, and K. L. Larson, 2008: The mirage in the Valley of the Sun. Environ. Hist., 13, 482-514.

Hong, S.-Y., J. Dudhia, and S.-H. Chen, 2004: A revised approach to ice-microphysical processes for the bulk parameterization of cloud and precipitation. Mon. Wea. Rev., 132, 103-120.

Hope, D., and Coauthors, 2003: Socio-economics drive urban plant diversity. Proc. Natl. Acad. Sci. USA, 100, 8788-8792.

Huth, R., J. Kysely, and L. Pokorna, 2000: A GCM simulation of heat waves, dry spells, and their relationship to circulation. Climatic Change, 46, 29-60.

Janjic, Z. I., 2002: Nonsingular implementation of the MellorYamada Level 2.5 Scheme in the NCEP Meso model. NCEP Office Note 437, $61 \mathrm{pp}$.

Jenerette, G. D., S. L. Harlan, A. Brazel, N. Jones, L. Larsen, and W. L. Stefanov, 2007: Regional relationships between surface temperature, vegetation, and human settlement in a rapidly urbanizing ecosystem. Landscape Ecol., 22, 353-365.

Kabat, P., and Coauthors, Eds., 2004: Vegetation, Water, Humans and the Climate: A New Perspective on an Interactive System. Global Change: The IGBP Series, Springer Verlag, 566 pp.

Kain, J. S., 2004: The Kain-Fritsch convective parameterization: An update. J. Appl. Meteor., 43, 170-181.

Karl, T. R., and R. W. Knight, 1997: The 1995 Chicago heat wave: How likely is a recurrence? Bull. Amer. Meteor. Soc., 78, 11071119.

Kimball, B. A., and Coauthors, 1994: Effects of free-air $\mathrm{CO}_{2}$ enrichment on energy balance and evapotranspiration of cotton. Agric. For. Meteor., 70, 259-278.

Kusaka, H., and F. Kimura, 2004: Thermal effects of urban canyon structure on the nocturnal heat island: Numerical experiment using a mesoscale model coupled with an urban canopy model. J. Appl. Meteor., 43, 1899-1910.

Liu, Y., F. Chen, T. Warner, and J. Basara, 2006: Verification of a mesoscale data-assimilation and forecasting system for the Oklahoma City area during the Joint Urban 2003 Field Project. J. Appl. Meteor. Climatol., 45, 912-929.

Lo, J. C. F., A. K. H. Lau, F. Chen, J. C. H. Fung, and K. K. M. Leung, 2007: Urban modification in a mesoscale model and the effects on the local circulation in the Pearl River Delta region. J. Appl. Meteor. Climatol., 46, 457-476.

Loridan, T., and Coauthors, 2010: Trade-offs and responsiveness of the single-layer urban canopy parametrization in WRF: An offline evaluation using the MOSCEM optimization algorithm and field observations. Quart. J. Roy. Meteor. Soc., 136, $997-$ 1019.

Maricopa Association of Governments, cited 2007: Arizona's future-Population projections from 2000-2050. [Available online at http://www.mag.maricopa.gov/pdf/cms.resource/ IS_2007_ArizonasFuture_2000-2050_LRG73684.jpg.]

Martilli, M., 2007: Current research and future challenges in urban mesoscale modeling. Int. J. Climatol., 27, 1909-1918.

McAdam, J. W., and A. L. Barta, 2007: Irrigation and water management. Forages: The Science of Grassland Agriculture, R. F. Barnes et al., Eds., Blackwell Publishing, 381.
Meehl, G. A., and C. Tebaldi, 2004: More intense, more frequent, and longer lasting heat waves in the 21st century. Science, 305, 994-997.

Mitchell, V. G., H. A. Cleugh, C. S. B. Grimmond, and J. Xu, 2008: Linking urban water balance and energy balance models to analyse urban design options. Hydrol. Processes, 22, 28912900.

Mlawer, E. J., S. J. Taubman, P. D. Brown, M. J. Iacono, and S. A. Clough, 1997: Radiative transfer for inhomogeneous atmosphere: RRTM, a validated correlated-k model for the longwave. J. Geophys. Res., 102, 16 663-16 682.

Moeller, M., cited 2005: Land cover classification using Landsat (MSS) data-Year 1973. [Available online at http://caplter. asu.edu/data/?path=/exist/rest/db/datasets/util/xquery/ getDatasetById.xql?_xsl=/db/datasets/util/xslt/datasetHTML. xsl\&id=knb-lter-cap.286.1.]

Nowak, D. J., K. L. Civerolo, S. T. Rao, G. Sistla, C. J. Luley, and D. E. Crane, 2000: A modeling study of the impact of urban trees on ozone. Atmos. Environ., 34, 1601-1613.

Oke, T. R., 1987: Boundary Layer Climates. Routledge, 435 pp.

Pielke, R. A., Sr., G. Marland, R. A. Betts, T. N. Chase, J. L. Eastman, J. O. Niles, D. Niyogi, and S. Running, 2002: The influence of land-use change and landscape dynamics on the climate system: Relevance to climate-change policy beyond the radiative effect of greenhouse gases. Philos. Trans. Roy. Soc. London, A360, 1705-1719.

Ruddell, D. M., S. L. Harlan, S. Grossman-Clarke, and A. Byuntajev, 2009: Risk and exposure to extreme heat in microclimates of Phoenix, AZ. Geospatial Contributions to Urban Hazard and Disaster Analysis, P. Showalter and Y. Lu, Eds., Springer, 179-202.

Sailor, D. J., and L. Lu, 2004: A top-down methodology for developing diurnal and seasonal anthropogenic heating profiles for urban areas. Atmos. Environ., 38, 2737-2748.

Seager, R., and Coauthors, 2007: Model projections of an imminent transition to a more arid climate in southwestern North America. Science, 316, 1181-1184.

Skamarock, W. C., and Coauthors, 2008: A description of the advanced research WRF version 3. NCAR Tech. Note NCAR/ TN-475+STR, 113 pp.

Stabler, L. B., C. A. Martin, and A. J. Brazel, 2005: Microclimates in a desert city were related to land use and vegetation index. Urban For. Urban Greening, 3, 137-147.

Stefanov, W. L., M. S. Ramsey, and P. R. Christensen, 2001: Monitoring urban land cover change: An expert system approach to land cover classification of semiarid to arid urban centers. Remote Sens. Environ., 77, 173-185.

United Nations, 2007: State of the World Population 2007: Unleashing the Potential of Urban Growth. United Nations Population Fund, 108 pp.

Zhang, C. L., F. Chen, S. G. Miao, Q. C. Li, X. A. Xia, and C. Y. Xuan, 2009: Impacts of urban expansion and future green planting on summer precipitation in the Beijing metropolitan area. J. Geophys. Res., 114, D02116, doi:10.1029/ 2008JD010328. 